TABLE II - Variability in blood pressure measurements expressed as coefficient of variability

\begin{tabular}{|c|c|c|c|c|}
\hline & & $\begin{array}{l}\text { Patients in } \\
\text { sinus rhythm } \\
(n=50)\end{array}$ & $\begin{array}{l}\text { Patients in } \\
\text { atrial fibrillation } \\
(\mathrm{n}=50)\end{array}$ & $\begin{array}{l}\mathrm{p} \text { Value } \\
\text { (Mann- } \\
\text { Whitney } \\
\text { U test) }\end{array}$ \\
\hline \multicolumn{5}{|c|}{ Interobserver variability } \\
\hline $\begin{array}{l}\text { Systolic blood pressure } \\
(\mathrm{mm} \mathrm{Hg})\end{array}$ & $\begin{array}{l}\text { Range } \\
\text { Median } \\
\text { Median difference between } \\
\text { groups }(95 \% \text { confidence interval })\end{array}$ & 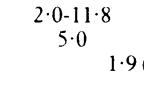 & $\begin{array}{r}1 \cdot 5-28 \cdot 0 \\
7 \cdot 0 \\
0 \cdot 3 \text { to } 3 \cdot 2)\end{array}$ & $0 \cdot 0013$ \\
\hline $\begin{array}{l}\text { Diastolic blood pressure } \\
\quad(\mathrm{mm} \mathrm{Hg})\end{array}$ & $\begin{array}{l}\text { Range } \\
\text { Median } \\
\text { Median difference between } \\
\quad \text { groups }(95 \% \text { confidence interval })\end{array}$ & $\begin{array}{l}1 \cdot 6-33 \cdot 6 \\
5 \cdot 90 \\
3 \cdot 3\end{array}$ & $\begin{array}{c}3 \cdot 4-27 \cdot 4 \\
9 \cdot 65 \\
1 \cdot 5 \text { to } 4 \cdot 9)\end{array}$ & $0 \cdot 0009$ \\
\hline \multicolumn{5}{|c|}{ Intraobserver variability } \\
\hline $\begin{array}{l}\text { Systolic blood pressure } \\
\text { (mm Hg) }\end{array}$ & $\begin{array}{l}\text { Range } \\
\text { Median } \\
\text { Median difference between } \\
\text { groups }(95 \% \text { confidence interval })\end{array}$ & $\begin{array}{l}0 \cdot 7 \cdot 14 \cdot 3 \\
3 \cdot 8 \\
\quad 1 \cdot 0\end{array}$ & $\begin{array}{r}0 \cdot 4-18 \cdot 2 \\
5 \cdot 3 \\
-0 \cdot 3 \text { to } 2 \cdot 2)\end{array}$ & $0 \cdot 140$ \\
\hline $\begin{array}{l}\text { Diastolic blood pressure } \\
\quad(\mathrm{mm} \mathrm{Hg})\end{array}$ & $\begin{array}{l}\text { Range } \\
\text { Median } \\
\text { Median difference between } \\
\quad \text { groups }(95 \% \text { confidence interval })\end{array}$ & $\begin{array}{l}0 \cdot 8-18 \cdot 0 \\
4 \cdot 15 \\
\quad 1 \cdot 7\end{array}$ & $\begin{array}{c}1 \cdot 0-26 \cdot 3 \\
6 \cdot 15 \\
0 \cdot 3 \text { to } 3 \cdot 2)\end{array}$ & $0 \cdot 012$ \\
\hline
\end{tabular}
variability with other factors

\begin{tabular}{|c|c|c|c|c|}
\hline & $\begin{array}{c}\text { SD systolic } \\
\text { blood } \\
\text { pressure }\end{array}$ & $\begin{array}{l}\text { Systolic } \\
\text { blood } \\
\text { pressure }\end{array}$ & Age & Pulse rate \\
\hline \multicolumn{5}{|c|}{ Sinus rhythm } \\
\hline SD systolic blood pressure & - & $0 \cdot 28$ & $0 \cdot 004$ & $-0 \cdot 100$ \\
\hline Systolic blood pressure & - & - & 0.057 & -0.098 \\
\hline Age & - & - & & -0.007 \\
\hline \multicolumn{5}{|c|}{$\mathrm{p}>0.05$} \\
\hline \multicolumn{5}{|c|}{ Atrial fibrillation } \\
\hline SD systolic blood pressure & - & $0 \cdot 195$ & -0.066 & $-0 \cdot 151$ \\
\hline Systolic blood pressure & - & - & $0 \cdot 125$ & 0.066 \\
\hline Age & - & - & - & -0.045 \\
\hline
\end{tabular}

bias, digit preference, and auditory acuity. ${ }^{5111}$ No study has sought to exclude these sources of error and look specifically at the influence of cardiac rhythm on observer variation. The important finding of our study is that atrial fibrillation is associated with a greater interobserver variability in the measurement of blood pressure but does not seem to affect intraobserver variability to the same extent. This suggests that the source of the increased variability is individual doctors' different interpretation of Korotkoff sounds. In atrial fibrillation there is baseline variation in blood pressure and the onset and disappearance of the sounds are more difficult to identify with a specific pressure reading.

There are at present no recommendations for measuring blood pressure in atrial fibrillation, so that some doctors may record systolic pressure at the first appearance of sounds whereas others may wait until these are consistently present. A similar problem may arise with the disappearance of sounds and the recording of diastolic pressure. Guidelines should make it possible to overcome this increased observer variation by using the first appearance and final disappearance of the sounds to record systolic and diastolic pressures. This, however, may result in the overestimation of the effective systolic pressure and an artificially lowered reading for the diastolic pressure. The order of magnitude of the variability found is $10 \%$, which would certainly be enough to affect clinical management decisions. The difficulties in setting guidelines for a single estimate of blood pressure suggest that a more prudent course would be to use repeated recordings. This reinforces the importance of not making decisions on the basis of a single recording, particularly in the presence of atrial fibrillation.

We thank Dr T J Peters for statistical advice and Mrs A Douglas for secretarial work.

1 Amery A, Birkenhager W, Bulpitt C, et al. Mortality and morhidity results from the European Working Party on High Blood Pressure in the Elderls trial EWPHE Lance 1985;:1349-5

2 Veterans Administration Cooperative Studv Group on Antihipertensive Agents. Effects of treatment on morbidity in hypertension. F.A.MA 1970; Agents. Effeets

3 Jackson G, Mahon W, Pierscianowsky TA, et al. Inappropriate antihspertensive therapy in the elderlv. Lancet 1976;ii: 1317 .

+ Wolf PA, Dawher TR, Thomas HE, et al. Epidemiologic assessment of chronic atrial fibrillation and risk of stroke: the Framingham study. Neurology 1978:28:973-7.

5 Bruce NG, Shaper AG, Walker M, et al. Observer bias in blood pressure studies. F Hypertens 1988;6:375-80

6 Petrie JC, O'Brien ET, Littler WA, et al. Recommendations on blood pressure measurement by a working party of the British Hypertension Society. Br.Med J 1986;293:611-5

7 Campbell MJ, Gardner MJ. Calculating confidence intervals for some nonparametric analyses. In: Gardner MJ, Altman DG, eds. Confidence intervals and statistical guidelines. London: British Medical Journal, 1989:74-9.

8 Hla KM, Vokaty KA, Feussner JR. Observer error in systolic blood pressure me. Woknts

9 Nielsen PE, Oxenboll B, Astrad K, et al. Auscultatory measurement of blood pressure performed by the doctor on duty. Acta Med Scand 1975;198:35-7.

10 Patterson HR. Sources of error in recording the blood pressure of patients with hypertension in general practice. Br.Med f 1984;289:1661-4.

11 O'Brien E, Fitzgerald D, O'Malley K. Blood pressure measurement: current practice and future trends. Br. Med $\mathcal{F}$ 1985:290:729-34.

Accepted 28 November 1989
Departments of

Gastroenterology and

Chemical Pathology,

Charing Cross Hospital,

London W6 8RF

Richard H T Loke, MRCP, research fellow

Iain M Murray-Lyon, FRCP, consultant physician and

gastroenterologist

Graham D Carter, MSC,

principal biochemist

Correspondence to: $\operatorname{Dr} \mathrm{R} \mathrm{H}$

T Loke, Department of

Gastroenterology,

University College Hospital,

London WC1.

BrMed f 1990;300:163-4

\section{Postural hypotension related to zidovudine in a patient infected with HIV}

\author{
Richard H T Loke, Iain M Murray-Lyon, \\ Graham D Carter
}

Disease of the adrenal glands is common in patients with AIDS. ${ }^{12}$ Clinical adrenocortical insufficiency, though less common, is increasingly recognised. ${ }^{3}$ We report a case in which adrenocortical insufficiency was brought to our attention by symptoms repeatedly precipitated by zidovudine.

\section{Case report}

A 49 year old homosexual first presented in October 1987 with an eczematous rash and mild oral candidiasis. His rash cleared after a short course of $0.025 \%$ betamethasone ointment. He had serological evidence of past hepatitis B infection and of antibodies to HIV. In April 1988 he received a two week course (his first) of ketoconazole for oral candidiasis.

Because of tiredness, weight loss (body weight $53 \mathrm{~kg})$, and a reduced CD4-lymphocyte count $(0.055$ $\times 10^{4} / \mathrm{l}$ ) he was started on zidovudine $200 \mathrm{mg}$ every four hours in June. Within an hour after his first oral dose he experienced hunger and dizziness for about 30 minutes, and these recurred after every subsequent dose. He was monitored before and after his dose, at 8 am, before breakfast. Twenty eight minutes after the dose he experienced his usual symptoms. Blood pressure (while he was seated) had decreased from a baseline of $115 / 65 \mathrm{mg} \mathrm{Hg}$ to $90 / 50 \mathrm{~mm} \mathrm{Hg}$ and was $90 /$ 60 and $86 / 60 \mathrm{~mm} \mathrm{Hg} 15$ and 30 minutes thereafter, increasing to $110 / 74 \mathrm{~mm} \mathrm{Hg}$ two hours after the dose. He was pale, but his pulse remained regular and stable, ranging from 76 to 84 beats $/ \mathrm{min}$. Plasma sodium, potassium, calcium, albumin, and phosphate concentrations $0,30,60,90,120$, and 150 minutes after the dose were normal and did not change appreciably; the corresponding fasting blood glucose values were 3.9 , $3 \cdot 7,3 \cdot 5,3 \cdot 5,3 \cdot 7$, and $3 \cdot 6 \mathrm{mmol} / \mathrm{l}$. 
Symptoms related to blood pressure, pulse rate, and blood concentrations of cortisol, zidovudine, and the 5O-glucuronide of zidovudine (GAZT) in patient given zidovudine $200 \mathrm{mg}$ and placebo

\begin{tabular}{|c|c|c|c|c|c|c|c|c|}
\hline \multirow[b]{2}{*}{$\begin{array}{l}\text { Time } \\
(\mathrm{min})\end{array}$} & \multicolumn{2}{|c|}{ Patient supine } & \multicolumn{2}{|c|}{ Patient erect } & \multirow{2}{*}{$\begin{array}{l}\text { Plasma } \\
\text { cortisol } \\
(\mathrm{nmol} / \mathrm{l})\end{array}$} & \multirow[b]{2}{*}{$\begin{array}{c}\mathrm{GAZT} \\
(\mu \mathrm{mol} / \mathrm{l})\end{array}$} & \multirow[b]{2}{*}{$\begin{array}{l}\text { Zidovudine } \\
(\mu \mathrm{mol} / \mathrm{l})\end{array}$} & \multirow[b]{2}{*}{ Symptoms } \\
\hline & $\begin{array}{l}\text { Blood pressure } \\
(\mathrm{mm} \mathrm{Hg})\end{array}$ & $\begin{array}{c}\text { Pulse } \\
\text { (beats/min) }\end{array}$ & $\begin{array}{l}\text { Blood pressure } \\
(\mathrm{mm} \mathrm{Hg})\end{array}$ & $\begin{array}{c}\text { Pulse } \\
\text { (beats/min) }\end{array}$ & & & & \\
\hline \multicolumn{9}{|c|}{ Zidovudine $200 \mathrm{mg}$ given at time 0} \\
\hline-30 & $113 / 72$ & 87 & $112 / 69$ & 98 & & $<2 \cdot 0$ & $<0.25$ & None \\
\hline 0 & $112 / 69$ & 84 & $115 / 69$ & 91 & 204 & $<2 \cdot 0$ & $<0.25$ & None \\
\hline 30 & $131 / 74$ & 76 & $108 / 68$ & 89 & & $24 \cdot 2$ & $5 \cdot 6$ & $\begin{array}{l}\text { Slightly } \\
\text { dizzy }\end{array}$ \\
\hline 40 & $111 / 65$ & 80 & Unrecordable & & & & & $\begin{array}{l}\text { Very giddy, } \\
\text { hungry, } \\
\text { pale }\end{array}$ \\
\hline 50 & $123 / 74$ & 74 & $118 / 65$ & 83 & & & & \\
\hline 60 & $107 / 70$ & 81 & $119 / 69$ & 98 & 139 & $19 \cdot 1$ & $2 \cdot 5$ & $\begin{array}{l}\text { Less gidd,y, } \\
\text { hungry }\end{array}$ \\
\hline 75 & $111 / 73$ & 76 & $112 / 71$ & 93 & & & & $\begin{array}{l}\text { Not giddy, } \\
\text { hungry }\end{array}$ \\
\hline 90 & $116 / 70$ & 80 & $118 / 75$ & 90 & 120 & $7 \cdot 7$ & $1 \cdot 4$ & None \\
\hline 120 & $125 / 75$ & 77 & $126 / 74$ & 100 & 111 & $4 \cdot 3$ & $1 \cdot 0$ & \\
\hline \multirow{2}{*}{\multicolumn{9}{|c|}{$\begin{array}{c}\text { 123/67 } \\
\text { Placebo given at time } 0\end{array}$}} \\
\hline & & & & & & & & \\
\hline-30 & $108 / 66$ & 86 & $109 / 58$ & 93 & 233 & $<2 \cdot 0$ & $<0 \cdot 25$ & \\
\hline 0 & $114 / 72$ & 82 & $105 / 66$ & 92 & 191 & $<2 \cdot 0$ & $<0 \cdot 25$ & \\
\hline 30 & $119 / 73$ & 81 & $117 / 74$ & 92 & 147 & $<2 \cdot 0$ & $<0.25$ & \\
\hline 40 & $124 / 72$ & 82 & $119 / 70$ & 88 & & & & \\
\hline 50 & $120 / 71$ & 79 & $122 / 69$ & 90 & & & & \\
\hline 60 & $124 / 77$ & 80 & $120 / 69$ & 90 & 125 & $<2 \cdot 4$ & $<0 \cdot 30$ & \\
\hline 75 & $114 / 72$ & 78 & $117 / 66$ & 94 & & & & \\
\hline 90 & $116 / 68$ & 77 & $124 / 67$ & 95 & 94 & $<2 \cdot 0$ & $<0 \cdot 25$ & \\
\hline 120 & $117 / 71$ & 75 & $115 / 68$ & 90 & 99 & $<2 \cdot 4$ & $<0 \cdot 30$ & \\
\hline 150 & $117 / 73$ & 75 & $120 / 64$ & 98 & 88 & $<2 \cdot 0$ & $<0.25$ & \\
\hline
\end{tabular}

Seven weeks later, at 7 am on consecutive mornings, a double blind placebo controlled challenge was performed. An intravenous cannula was inserted with the patient resting on an examination couch. Blood pressure and pulse rate were recorded with an electronic Colin sphygmomanometer (103 N Mark 3) half an hour before the drug was given; when the patient took two unmarked capsules; and at set intervals thereafter. The patient independently recorded any symptoms. Blood $(20 \mathrm{ml})$ was taken via the cannula at set intervals and aliquots of plasma and serum immediately frozen at $-20^{\circ} \mathrm{C}$. Blinded specimens were assayed for both zidovudine (limit detection $0.25 \mu \mathrm{mol} / \mathrm{l}$ ) and a major metabolite, the 5-O-glucuronide of zidovudine (3azido-3-deoxy-5- $B$-D-glucopyranuronosylthymidine; GAZT) (limit of detection $2 \cdot 0 \mu \mathrm{mol} / \mathrm{l}$ ), by high performance liquid chromatography (table). There was no appreciable abnormality or fluctuation in serial concentrations of sodium, potassium chloride, bicarbonate, urea, creatinine, calcium, phosphate, albumin, and magnesium.
There was no evidence of autonomic neuropathy: the response of blood pressure and pulse to the Valsalva manoeuvre was normal. The short tetracosactrin stress test showed a suboptimal response from a baseline value of $362 \mathrm{nmol} / \mathrm{l}$ to $517 \mathrm{nmol} / \mathrm{l}$ at 30 minutes.

\section{Comment}

Postural hypotension related to zidovudine has not been reported previously. Dizziness, however, was reported in a small number of patients in both the group given zidovudine and the group given placebo in a controlled trial, but the nature and timing of the symptoms were not stated. ${ }^{4}$ In our patient the symptoms occurred only after he took zidovudine and coincided with the raised blood concentrations of both zidovudine and the metabolite that we measured. This drug profile corresponds with the published data on the pharmacokinetics and bioavailability of zidovudine in humans.

We postulate that zidovudine or its metabolites, or both, have a direct but transient vasomotor effect related to dose that is not clinically apparent unless there is underlying adrenocortical insufficiency. Even allowing for normal diurnal variation, the mid-morning plasma cortisol concentrations were subnormal and there was no increase in cortisol concentration related to stress. Alternatively, zidovudine may have a direct effect on the autonomic system. We do not think that the patient's previous short course of ketoconazole and weak topical betamethasone were contributory.

RHTL was supported by the Bernard Sunley Foundation. We thank Drs P A Cload and C C Chan of Wellcome Research Laboratories, Beckenham, Kent, for supplying the unmarked zidovudine and placebo and for measuring the drug concentrations and Professor A Fleck for advice.

1 Glasgow BJ, Steinsapir KD, Anders K, Layfield LJ. Adrenal pathology in the acquired immune deficiency syndrome. Am $\mathcal{F}$ Clin Pathol 1985;84:94-7.

Aron DC. Endocrine complications of the acquired immunodeficiency syndrome. Arch Intern Med 1989;149:330-3.

3 Guy RJC, Turberg Y, Davidson RN, Finnerty G, MacGregor GA, Wise PH. Mineralocorticoid deficiency in HIV infection. Br Med f 1989;298:498-9.

Richman DD, Fiscal MA, Grieco MH, et al. The toxicity of azidothymidine (AZT) in the treatment of patients with AIDS and AIDS-related complex $N$ Engl I Med 1987;317:192-7.
En

5 Blum MR, Liao SHT, Good SS, De Miranda P. Pharmacokinetics and bioavailability of zidovudine in humans. Am F Med 1988;85(suppl 2A): 18994.

(Accepted 21 September 1989)

\section{Westminster Hospital, London SW1P 2AP, M Bower, MRCP, registrar in general medicine and $H I V$ related medicine $M$ Nelson, MA, registrar in general medicine and HIV related medicine \\ B G Gazzard, FRCP, consultant physician and AIDS coordinator}

Correspondence to: Dr Gazzard.

BrMed f 1990;300:164-5

\section{Dupuytren's contractures in patients infected with HIV}

\section{Bower, M Nelson, B G Gazzard}

A free radical mechanism for the pathogenesis of Dupuytren's contracture has been established, ${ }^{1}$ and there is evidence for increased activity of free radicals in patients infected with HIV. ${ }^{2}$ We compared the prevalence of Dupuytren's contractures in such patients with that in patients negative for HIV.

\section{Patients, methods, and results}

Fifty men (age range 19-54) serially admitted to hospital with complications of HIV infection were examined independently by two doctors for clinical evidence of Dupuytren's contractures. These were regarded as present only if both doctors agreed. A control group of 50 men seen as outpatients in a sexually transmitted disease clinic, who were negative for HIV antibody, were examined similarly.
The men's occupational histories and histories of alcohol consumption, epilepsy, diabetes mellitus, and all current medicines were obtained. Their livers were examined for hepatomegaly clinically and by ultrasonography or computed tomography; liver function was assessed by measurement of aspartate aminotransferase, alanine aminotransferase, and alkaline phosphatase activities; and fasting blood glucose concentration was measured. In the patients with HIV infection the date on which HIV antibody had first been detected was noted and plasma p24 antigen concentrations and CD4+ lymphocyte counts were measured (table).

All 50 patients with HIV antibodies had advanced disease ( 48 had stage IV, as classified by the Centers for Disease Control, and two stage III). Eighteen of these patients had Dupuytren's contractures (nine bilateral). One clinician thought that a thickening of the palmar aponeurosis was present in a further six patients (these were not included in the analysis). None of the 50 control patients had Dupuytren's contractures. Among the patients infected with HIV raised fasting blood glucose concentrations, biochemical abnormalities of liver function, hepatomegaly, high alcohol 